\title{
Characterisation of Chilean hazelnut (Gevuina avellana) tissues: light microscopy and cell wall polysaccharides
}

\author{
Fernando Dourado, ${ }^{1}$ Pedro Vasco, ${ }^{2}$ António Barros, ${ }^{2}$ Manuel Mota, ${ }^{1}$ \\ Manuel A Coimbra ${ }^{2}$ and Francisco M Gama ${ }^{1 *}$ \\ ${ }^{1}$ Centro de Engenharia Biológica, IBQF, Largo do Paço, Universidade do Minho, P-4710-057 Braga, Portugal \\ ${ }^{2}$ Departamento de Química, Universidade de Aveiro, P-3810-193 Aveiro, Portugal
}

\begin{abstract}
By applying several differential staining techniques and light microscopy, the structure and composition of Chilean hazelnut (Gevuina avellana) seeds were analysed. The structure of the $G$ avellana seed is very simple, with a thin, heavily lignified seed coat and two voluminous cotyledons. The embryo food reserves are uniformly distributed over the cotyledon cells. The cell wall polysaccharides were recovered from the alcohol-insoluble residue by mild treatment with warm chlorite solution and sequential extraction with alkali solutions of increasing concentration. FT-IR spectra in the $1200-850 \mathrm{~cm}^{-1}$ region were used together with chemometric techniques to distinguish the hemicellulosic and pectic polysaccharides in the extracts. The most abundant extracts were fractionated by graded precipitation in ethanol. A xyloglucan was identified by ${ }^{1} \mathrm{H}$ and ${ }^{13} \mathrm{C}$ NMR as the major hemicellulosic polysaccharide, with a sugar composition of 4Glc:3.5Xyl:1Gal:0.5Fuc. The hazelnut cell walls are composed of equivalent amounts of pectic polysaccharides, xyloglucans and cellulose.
\end{abstract}

(C) 2003 Society of Chemical Industry

Keywords: hazelnut; Gevuina avellana; seed structure; cell walls; light microscopy; FT-IR; xyloglucan

\section{INTRODUCTION}

The plant cell wall is primarily composed of polysaccharides, which can be classified as cellulose, and cell wall matrix components, namely pectins and hemicelluloses. ${ }^{1}$ Xyloglucans make up about $20 \%$ of the primary cell walls of dicotyledonous plants. ${ }^{2}$ Xyloglucans are neutral polysaccharides composed of a linear backbone of $\beta$-D- $(1 \rightarrow 4)$-Glc $p$ branched at C- 6 with $\alpha$ $\mathrm{D}-\mathrm{Xyl} p$. The Xyl may also be substituted at C-2 by $\beta$ $\mathrm{Gal} p$, and this residue may be substituted at C-2 by $\alpha$-L-Fuc $p$, giving highly branched structures.

Cell wall polysaccharides are used in foods as thickeners, stabilisers, gelling agents and, in some cases, emulsifiers. ${ }^{3}$ Their inclusion in foods permits the manufacture of a vast array of products which are not only stable to a wide range of transport and storage conditions but also have the properties desired by the consumer. ${ }^{4}$

Growing knowledge of the cell wall composition and structure has led to a better understanding of (1) the physiological role of polysaccharides in dietary fibre, ${ }^{5-7}$ (2) agro-industrial applications of seed or fruit meals, ${ }^{8,9}$ (3) the enzymatic degradation of poly- saccharides ${ }^{8,10-15}$ and (4) the chemistry of texture changes of foods. ${ }^{16-19}$ Also, in recent years, polysaccharides of plant origin have emerged as an important class of bioactive natural products. ${ }^{20-22}$

FT-IR spectroscopy in association with chemometric techniques, when applied in the wavenumber region between 1200 and $850 \mathrm{~cm}^{-1}$, has been used as a reliable and fast method for evaluation of the polysaccharide composition of pectic and hemicellulosic samples derived from orange and olive tissues ${ }^{23,24}$ and to follow the effects of processing on cell wall polysaccharide extracts of fresh and dried pears. ${ }^{25}$ This methodology was used here to characterise the cell wall polysaccharides extracted from the Chilean hazelnut (Gevuina avellana Mol, fam Proteaceae). Also, a histological study on elucidation of the seed structure and location of the embryo food reserves was carried out. Information regarding this fruit is rather scarce. Currently under-exploited, it can be a valuable alternative when considering food sources with high protein and oil content (rich in unsaturated fatty acids). ${ }^{26}$ The high content of palmitoleic acid $(37 \%)^{26}$ increases the importance of the hazelnut oil for

* Correspondence to: Francisco M Gama, Centro de Engenharia Biológica, IBQF, Largo do Paço, Universidade do Minho, P-4710-057 Braga, Portugal

E-mail: fmgama@deb.uminho.pt

Contract/grant sponsor: INCO-DC; contract/grant number: 96-2205

Contract/grant sponsor: Research Unit 62/94, QOPNA (Aveiro, Portugal)

Contract/grant sponsor: FCT (Portugal); contract/grant number: PRAXIS XXI/BPD/18824/99

(Received 4 April 2002; accepted 16 May 2002) 
cosmetic purposes. The hazelnut flour (either whole or defatted) is normally used in confectionery, as an additive in children's foods and to feed livestock.

The protein content of the defatted flour is comparable to the that of legumes and much higher than that of cereals, while the content of crude fibre is higher than that of legumes, cereals and some oil seeds. ${ }^{26}$ According to Villarroel et al, ${ }^{26}$ the true protein digestibility of the hazelnut flour is significantly lower than that of casein, possibly owing to the high fibre content of the hazelnut flour. Enzymatic treatment of the polysaccharide fraction of these seeds could therefore enhance their agro-industrial applications. However, the enzyme preparations must have a broad spectrum of activity owing to the complex structure of the cell walls. ${ }^{27}$ In order to define more precisely the type(s) of enzyme(s) required to degrade the cell wall polysaccharides, and consequently increase the efficiency of degradation of the hazelnut cell walls, polysaccharides were extracted and characterised.

\section{MATERIALS AND METHODS Plant material}

$G$ avellana fruits were kindly supplied from Chile by Dr Rolando Chamy (Universidad Católica de Valparaíso). Average seed moisture content was $5 \%(\mathrm{w} / \mathrm{w}$, dry basis). Average pericarp size was $0.5 \mathrm{~cm}$, maximum seed coat size was $0.1 \mathrm{~mm}$ and the mature seed, a spherical structure, had a diameter of approximately $1 \mathrm{~cm}$. The fruits were stored in a closed plastic bag at $4{ }^{\circ} \mathrm{C}$ and analysed within 1 year.

\section{Optical microscopy}

\section{Sample preparation}

The fruit pericarp was removed by hammer breaking, and the seed coat was manually removed after boiling for $5 \mathrm{~min}$ in distilled water. The boiling step softens the seed coat, thus facilitating its removal; boiling also inhibits endogenous enzymatic activity. Seeds were fixed overnight at $4{ }^{\circ} \mathrm{C}$ with a mixture of formalin, acetic acid and $70 \%$ ethanol $(5: 5: 90 \mathrm{v} / \mathrm{v} / \mathrm{v})$. To facilitate embedding, seed slices $1 \mathrm{~mm}$ wide were obtained. Fixation was followed by washing with distilled water (several changes of water) for $4 \mathrm{~h}$. The sectioned seeds were dehydrated by immersion in a series of solutions according to the following procedure: $2 \times 50 \%$ ethanol; tert-butanol/ethanol/water mixtures of varying proportions $(1: 4: 5,2: 5: 3,7: 10: 3$ and 10:9:0 v/v/v); tert-butanol/absolute ethanol (3:1 $\mathrm{v} / \mathrm{v}$ ); and finally $2 \times$ tert-butanol (each step lasting no more than $5 \mathrm{~min}$ to minimise lipid extraction). Dehydrated seeds were embedded in tert-butanol and paraffin $(1: 1 \mathrm{v} / \mathrm{v})$ for $2 \mathrm{~h}$ at $60^{\circ} \mathrm{C}$ and then twice in paraffin at $60^{\circ} \mathrm{C}$ for $1 \mathrm{~h}$. The seeds were finally

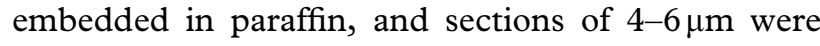
obtained with a Jung RM 2035 microtome (Leica).

\section{Staining}

Paraffin was removed from the sections by immersion in xylene and then in a mixture of xylene and absolute ethanol $(1: 1 \mathrm{v} / \mathrm{v})$, each step lasting $2 \mathrm{~min}$. Afterwards, sections were rehydrated in a graded ethanol series, starting from absolute ethanol to $50 \%$ ethanol (1 min each step). Ethanol concentration decreased by $10 \%$ at each rehydration stage. The solutions were all stored at $4{ }^{\circ} \mathrm{C}$ before use to minimise lipid extraction.

Sections were examined with the following staining methods: Safranin and Picro Aniline Blue (cellulose stains blue; lignin stains red); PAS (Periodic Acid Schiff's reagent)/Amido Black ${ }^{28}$ (proteins stain blue; carbohydrates stain red); Coomassie Brilliant Blue $\mathrm{R} 250^{29}$ (proteins stain blue); Toluidine Blue (phytin stains red; all other structures stain blue; lignin stains green); Red Oil O (lipids, cutin and waxes stain red); and Sudan Black ${ }^{30}$ (lipids, cutin and waxes stain black). For lipid staining, sections were stained for $30 \mathrm{~min}$.

The original mounting medium referred to in Ref 28 was Canada balsam. In this work we used Entellan in order to prevent colour fading.

\section{Isolation of cell wall polysaccharides}

After removal of the pericarp and seed coat (as described above), seeds ( $72 \mathrm{~g}$ ) were ground in a coffee mill to a final particle size of approximately $0.5 \mathrm{~mm}$ after sieving. The material was refluxed in $300 \mathrm{ml}$ of ethanol for $15 \mathrm{~min}$ to inactivate the enzymes and extract the ethanol-soluble molecules. The mixture was then cooled and filtered through a size 1 sintered glass funnel (P160/ISO 4793, 100-160 $\mu \mathrm{m}$ pore size). In order to remove the oil, the residue was extracted twice with $300 \mathrm{ml}$ of chloroform/methanol $(2: 1 \mathrm{v} / \mathrm{v})$ solution for $30 \mathrm{~min}$ and then washed with absolute ethanol and diethyl ether before being placed in an oven at $40^{\circ} \mathrm{C}$ until no weight variation was detected. ${ }^{31}$ The obtained alcohol-insoluble residue (AIR) was stored in anhydrous conditions until use.

Since the amount of non-carbohydrate material in the AIR was relatively high, as shown by sugar analysis, the AIR (38.8g) was pre-treated for $30 \mathrm{~min}$ with $800 \mathrm{ml}$ of a reaction mixture containing $3 \mathrm{~g} \mathrm{l}^{-1} \mathrm{NaClO}_{2}$ and $1.2 \mathrm{ml}^{-1}$ glacial acetic acid at $70^{\circ} \mathrm{C}$. The oxidised material was extracted with $800 \mathrm{ml}$ of distilled water at $40^{\circ} \mathrm{C}$ for $75 \mathrm{~min}$ (Water-1) and then with $600 \mathrm{ml}$ of dimethyl sulphoxide (DMSO) at $20^{\circ} \mathrm{C}$ for $20 \mathrm{~h}$ and washed with distilled water $(4 \times 100 \mathrm{ml})$ to complete removal of DMSO (Water-2). The following sequential extractions were then performed: $0.5 \mathrm{M} \mathrm{KOH}$ $(800 \mathrm{ml})$ at $4{ }^{\circ} \mathrm{C}$ for $2 \mathrm{~h} ; 1 \mathrm{M} \mathrm{KOH}(800 \mathrm{ml})$ at $4{ }^{\circ} \mathrm{C}$ for $2 \mathrm{~h} ; 1 \mathrm{M} \mathrm{KOH}(800 \mathrm{ml})$ at $20^{\circ} \mathrm{C}$ for $2 \mathrm{~h}$; and finally $4 \mathrm{M}$ $\mathrm{KOH}(800 \mathrm{ml})$ at $20^{\circ} \mathrm{C}$ for $2 \mathrm{~h}$. To prevent $\beta$ elimination, peeling reactions and alkaline oxidation of the polysaccharides, $\mathrm{KOH}$ extractions were carried out under an inert atmosphere $\left(\mathrm{N}_{2}\right)$ with $\mathrm{O}_{2}$-free solutions containing $20 \mathrm{~mm} \mathrm{NaBH}_{4}$. KOH solutions were prepared using distilled water previously boiled for $20 \mathrm{~min}$ and cooled under a nitrogen atmosphere.

After each extraction step the mixture was filtered, concentrated under reduced pressure and dialysed for 
3 days, with several changes of distilled water. The alkali extracts were previously acidified to $\mathrm{pH} 5.0$ with glacial acetic acid. After dialysis, all the extracts were centrifuged $\left(24400 \times g, 20 \mathrm{~min}, 4^{\circ} \mathrm{C}\right)$ and the precipitates (ppt) were separated from the soluble material (supernatant, sn). Finally, the obtained fractions were concentrated and freeze-dried. The final residue (CR) was washed with distilled water, neutralised and dialysed. Both supernatant (sn-CR) and residue were separated by centrifugation and freeze-dried.

\section{Ethanol precipitation}

The following extracts were fractionated by ethanol precipitation: chlorite sn, $1 \mathrm{M} \mathrm{KOH}-2$ sn and $4 \mathrm{M}$ $\mathrm{KOH}-2$ sn. The freeze-dried samples were dissolved in water to a final concentration of $10 \mathrm{~g} \mathrm{l}^{-1}$, with gentle stirring (overnight if required). The non-dissolved material was removed by centrifugation $(24400 \times g$, $20 \mathrm{~min}, 4^{\circ} \mathrm{C}$ ), and ethanol was gradually added to the supernatant in steps between 10 and $20 \%$. In between each step of ethanol addition the mixture was left at $4{ }^{\circ} \mathrm{C}$ for $1 \mathrm{~h}$ and the precipitate was removed from the supernatant by centrifugation. The procedure was repeated with the supernatant to a final ethanol concentration of $80 \%$. In order to completely remove the ethanol, each precipitate was dissolved in water and rota-evaporated at $37^{\circ} \mathrm{C}$, since complete removal of the ethanol cannot be achieved by freeze-drying alone. $^{31}$

\section{Carbohydrate analysis}

Neutral sugars were released by Saeman hydrolysis and analysed as alditol acetates by gas-liquid chromatography in a Carlo Erba GC 6000 series 2 with an FID detector and a DB 225 column. Hexuronic acids (HexA) were determined colorimetrically using the $m$ phenylphenol method, ${ }^{32}$ as described in Ref 31 .

\section{NMR}

The sample $4 \mathrm{M} \mathrm{KOH}$ sn Et50 was dissolved in $\mathrm{D}_{2} \mathrm{O}$ to a final concentration of $44 \mathrm{~g}^{-1}$ and analysed by liquid quantitative ${ }^{13} \mathrm{C}$ and ${ }^{1} \mathrm{H}$ NMR using 3-(trimethylsilylpropionic-2,2,3,3- $d_{4}$ acid) sodium salt (TSS) as internal standard. A Brüker AMX 300 operating at a carbon frequency of $75.2 \mathrm{MHz}(318 \mathrm{~K})$ and at a proton frequency of $300.1 \mathrm{MHz}$ was used.

\section{FT-IR spectra}

FT-IR spectra of all cell wall extracts and ethanolprecipitated fractions were acquired with a GoldenGate single reflection ATR in a Bruker IFS-55 at $8 \mathrm{~cm}^{-1}$ resolution and 128 co-added scans. Five replicate spectra were obtained for each sample. Each spectrum was subjected to the SNV (standard normal deviate) preprocessing technique in order to determine baseline shifts and global variations in signal intensity. The spectra were transferred via JCAMP.DX format ${ }^{33}$ into the data analysis software package co-developed at the University of Aveiro and the Institut National Agronomique Paris-Grignon. ${ }^{34}$

\section{Principal component analysis (PCA)}

PCA is essentially a descriptive method. This method is normally the first step in data exploration, allowing a visualisation of the main variability aspects of a data set without the constraint of an initial hypothesis concerning the relationships within samples and between samples and responses (variables). The main goal of this procedure is to find relationships between the different parameters (objects and variables) or/and the detection of possible clusters within objects or/and variables.

In order to find the main sources of variability of a data set (FT-IR data of polysaccharide samples) and the relationship between and within objects ( $n$ FT-IR samples) and variables ( $m$ wavenumbers), the initial matrix $\mathbf{X}_{(n, m)}$ is decomposed into matrices that represent the object space (scores), the variable space (loadings) and errors (variation not accounted for by the extracted principal components).

The decomposition is formalised by

$$
\mathbf{X}_{(n, m)}=\mathbf{T}_{(n, k)} \mathbf{P}_{(k, m)}^{\mathrm{T}}+\mathbf{E}_{(n, m)}
$$

where $\mathbf{T}$ is the score matrix, $\mathbf{P}$ is the loading matrix, $\mathbf{E}$ is the error matrix, $n$ is the number of objects (samples), $m$ is the number of variables (in this study, wavenumbers) and $k$ is the number of principal components used.

\section{RESULTS AND DISCUSSION Optical microscopy}

$G$ avellana seed has a very simple structure (Plate 1 ). The mature embryo has two voluminous cotyledons. No remains of the endosperm tissue were detected, a common characteristic of exalbuminous seeds, ${ }^{35}$ where the aggressive development of the embryo destroys, partially or completely, the endosperm tissue.

The internal organisation of the cotyledon cells is quite homogeneous. These cells have a high number of protein bodies $(\mathrm{pb})$ or aleurone grains varying in size and shape (Plate 1A). These protein bodies have a high number of protein inclusions (pi) also varying in size and shape (data not shown). These inclusions may consist of crystal globoids, protein crystalloids or calcium oxalate crystals. Most of the crystalline inclusions were detached from the protein bodies during sectioning, since they are very hard structures. Hence, in Plate 1F, most sites of protein inclusions appear white. Mineral reserves are usually concentrated as globoid crystals and occur as phytin. ${ }^{36}$ These crystals stain violet red with Toluidine Blue (data not shown).

Plates 1C and 1D show the results obtained from lipid staining with Sudan Black and Red Oil O. It is interesting to observe that the protein bodies stained 

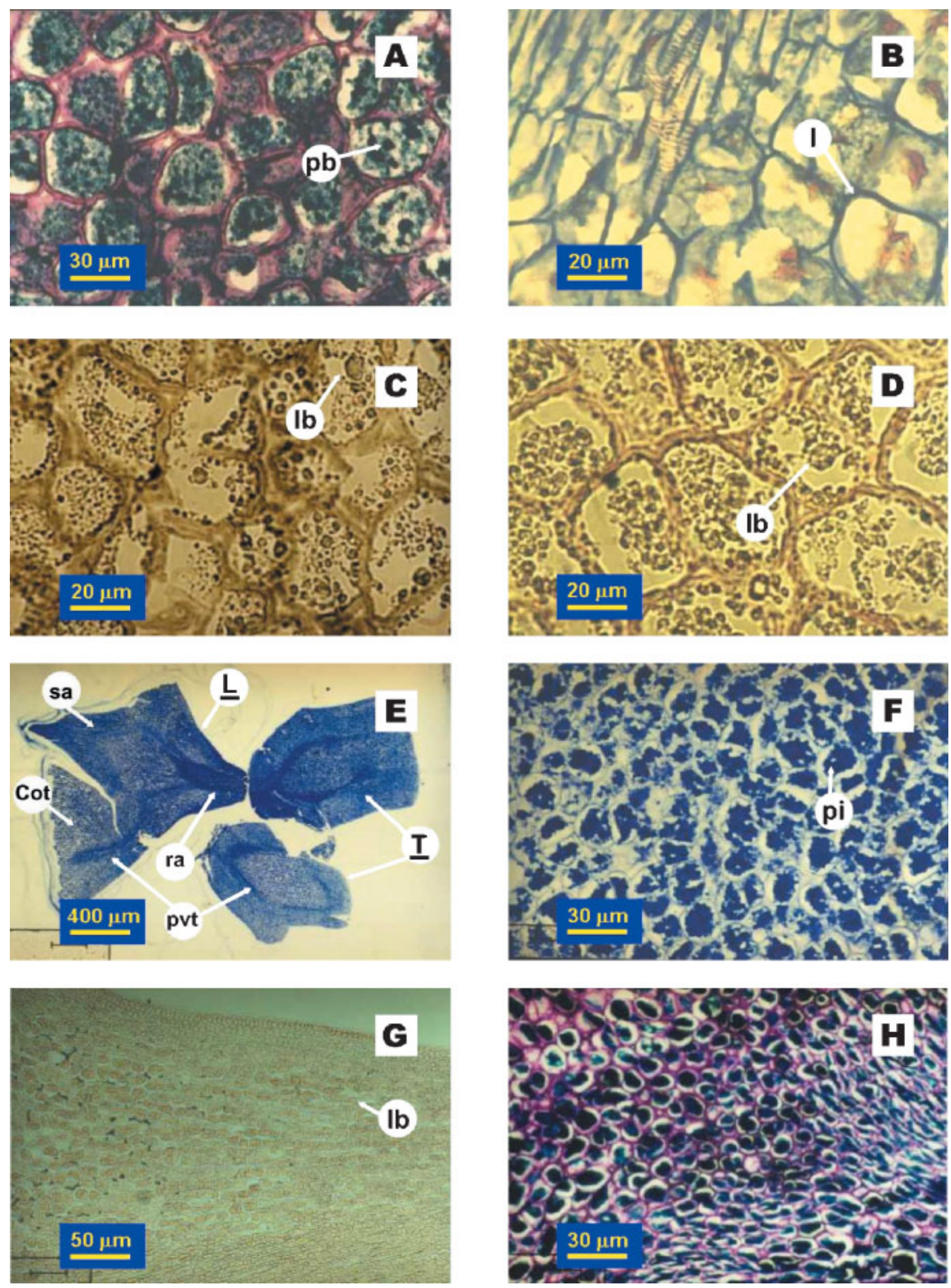

Plate 1. Light micrographs from longitudinal and transverse sections of mature seeds of Gevuina avellana. Magnifications: A, F and H, 400 ; B-D, 630 ; E, 25 ; G, 200 . Abbreviations: pb, protein bodies; pi, protein inclusions; lb, lipid bodies; I, lignin; pvt, provascular tissue; sa, shoot apex; ra, root apex; L, longitudinal section of embryo; I, transverse section of embryo; Cot, cotyledon. Parts: A-D, cotyledon cells; E, overview of embryonic axis; F, fraction of cotyledon cells at base of embryonic axis; $G$ and H, cells at base of embryonic axis. Staining: A and H, PASAmido Black; E and F, Coomassie Blue; C, Sudan Black; B, Safranin and Picro Aniline Blue; D and G, Red Oil O. 
with PAS/Amido Black (Plate 1A) and Coomassie Blue (data not shown) stain also with lipid-specific stains. In higher plant seeds, lipid storage occurs in the form of triacylglycerol lipid bodies (lb). The surface of these organelles basically consists of a phospholipid monolayer and a group of associated proteins, oleosins being the most abundant ones. ${ }^{37}$ Therefore it is possible that the observed protein bodies $(\mathrm{pb})$ and lipid bodies (lb) consist of a complex matrix composed of lipids and proteins. Considering the high lipid content of these seeds (approximately 50\%), it is possible that some small lipid droplets also exist in the cell cytoplasm (as shown in Plates 1C and 1D, the cytoplasm is also stained, although at lower intensity).

The cell walls of the cotyledons stain also with Sudan Black and Red Oil O (Plates 1C and 1D). This suggests the occurrence of lipids associated with the cell walls (probably as phospholipids or as components of structural proteins).

The embryo is surrounded by a monolayer of cells (data not shown). This layer corresponds to the embryo epidermis, developed from the embryo protoderm during growth.

As evidenced by the Safranin and Picro Aniline Blue staining (Plate 1B), the embryo cell walls are probably mainly composed of cellulose (stained blue). Some lignin (1) is also detectable. As a matter of fact, the light red staining of the cell walls in Plate 1B is unlikely to arise from non-specific staining, since, for instance, almond cotyledon tissues do not stain similarly (data not shown).

Cellulose was the major constituent of the cell walls. On the other hand, starch was undetected using the PAS/Amido Black staining. Chilean hazelnut seeds are therefore apparently rather scarce in intracellular carbohydrate reserves. However, hemicelluloses may also be included as storage reserves in some seeds. ${ }^{36}$ As shown below, hemicelluloses (xyloglucans) were found in the cell walls of $G$ avellana seeds.

Plate $1 \mathrm{E}$ shows a longitudinal $(\underline{\mathrm{L}})$ and a transverse (T) section of the embryo provascular tissue (pvt) (and a portion of the cotyledon (Cot)). In the longitudinal section the root apex (ra) and shoot apex (sa) are identified. These structures are distributed along the radial embryonic axis (right side in Plate 1E). Also visible in the fraction of the attached cotyledon is the provascular tissue (pvt). When observing both longitudinal and transverse sections of the cotyledons, the provascular tissue was not easily detected (data not shown). It is possible that, as also observed in the cotyledons of Rosa mosqueta, ${ }^{38}$ the provascular tissue is oriented in small bundles perpendicular to the transverse embryonic axis.

At the base of the embryonic axis the cells are much smaller (Plates $1 \mathrm{~F}-1 \mathrm{H}$ ) and have thinner walls as compared with the cells from the bulk of the cotyledons (Plates 1A, 1C and 1D). The intracellular material basically consists of a large globular mass, mainly of a lipid-protein matrix, this matrix containing a larger number of protein inclusions (Plate $1 \mathrm{~F}$ ). In addition, the cell walls are probably mainly composed of polysaccharides, since no lignin was detected (data not shown). Lipids were also detected in the lipidprotein matrix (Plate 1G).

The staining experiments aimed at locating the embryo food reserves (Plate 1) show that these are uniformly distributed over the entire cotyledon cells.

In this study we did not focus on the characterisation of the $G$ avellana seed coat, since it is very simple and thin. The structure consists mainly of a few layers of heavily lignified and empty cells, which were probably compressed during embryo development (data not shown).

\section{Isolation and analysis of cell wall polysaccharide extracts}

The Chilean hazelnut tissues were boiled in ethanol and the residue was extracted twice with chloroform/ methanol in order to remove the lipid fraction. The resultant AIR accounts for $54 \%$ of the initial seed weight. Glucose (34 mol\%) and arabinose ( $25 \mathrm{~mol} \%$ ) are the major sugars present. In all, xylose, galactose and hexuronic acid correspond to $30-35 \%$ of the total sugars, being present in similar amounts (Table 1). The carbohydrate content in the AIR (39\% of dry weight) indicates that the residue is mainly noncarbohydrate. As these tissues contain a high amount of intracellular proteins,${ }^{26}$ as confirmed by the staining studies, the low AIR sugar content indicates that they were co-precipitated with the cell wall polysaccharides. $^{31,39}$ This may also justify the high AIR yield obtained, much higher than that typically obtained for similar tissues (between 7 and 9\%). ${ }^{40}$ Mild warm chlorite treatment ${ }^{41}$ was performed in order to disrupt the non-carbohydrate polymeric network, although some degradation of acid-labile sugars may occur. ${ }^{31}$

The polysaccharide fractions solubilised with the chlorite treatment represented $1.3 \%$ of the AIR (Table 1). A small amount (13\%) precipitated upon dialysis. Although poor in sugars, both were rich in HexA, Ara and $\mathrm{Gal}$, a sugar composition characteristic of pectic polysaccharides.

DMSO is known to be a good solvent for xylans. ${ }^{39}$ The very low amount of carbohydrate material solubilised with DMSO, and its sugar composition, showed that the hemicellulosic material of the hazelnut seed was not of the xylan type. The extractions with 0.5 and $1 \mathrm{M} \mathrm{KOH}$ at $4{ }^{\circ} \mathrm{C}$ gave fractions very poor in sugars. However, the extracts obtained at room temperature with 1 and $4 \mathrm{~m} \mathrm{KOH}$, soluble upon neutralisation and dialysis, were very rich in sugars (Table 1). A small amount of pectic material still associated with the cellulosic residue was released upon neutralisation (sn-CR). The final CR is very poor in sugars $(30 \%)$ and is mainly composed of Glc (from cellulose). The total polymeric material recovered from the AIR by sequential extraction was only $52.4 \%$ (59.4\% of the AIR sugars), possibly because small molecules diffuse through the dialysis membrane. 
Table 1. Sugar composition of cell wall extracts from Gevuina avellana seeds

\begin{tabular}{|c|c|c|c|c|c|c|c|c|c|c|}
\hline \multirow[b]{2}{*}{ Fraction } & \multirow{2}{*}{$\begin{array}{c}\text { Recovery } \\
\left(\mathrm{g} \mathrm{kg}^{-1}\right)\end{array}$} & \multicolumn{8}{|c|}{ Cell wall sugars (mol\%) } & \multirow{2}{*}{$\begin{array}{c}\text { Total sugars } \\
\quad\left(m g g^{-1}\right)\end{array}$} \\
\hline & & Rha & Fuc & Ara & $x y l$ & Man & Gal & G/c & HexA & \\
\hline AIR & $538.8^{b}$ & 2 & 5 & 25 & 12 & 1 & 11 & 34 & 10 & 388 \\
\hline \multicolumn{11}{|l|}{ Chlorite } \\
\hline sn & $11.1^{\mathrm{c}}$ & 3 & 2 & 32 & 4 & 2 & 20 & 8 & 29 & 450 \\
\hline ppt & 1.6 & 2 & 1 & 19 & 3 & 4 & 12 & 9 & 50 & 323 \\
\hline \multicolumn{11}{|l|}{ Water-1 } \\
\hline sn & 1.1 & 6 & 3 & 19 & 1 & 2 & 15 & 7 & 47 & 217 \\
\hline ppt & 0.5 & 1 & 3 & 20 & 6 & 10 & 10 & 30 & 20 & 257 \\
\hline \multicolumn{11}{|l|}{ DMSO } \\
\hline sn & 1.2 & 3 & 2 & 20 & 15 & 4 & 18 & 29 & 9 & 399 \\
\hline ppt & 0.7 & 1 & 2 & 22 & 7 & 7 & 13 & 35 & 13 & 296 \\
\hline Water-2 & 0.8 & 2 & 2 & 21 & 8 & 4 & 15 & 19 & 30 & 338 \\
\hline \multicolumn{11}{|c|}{$0.5 \mathrm{M} \mathrm{KOH}$} \\
\hline sn & 19.6 & 3 & 1 & 27 & 8 & 6 & 21 & 14 & 21 & 213 \\
\hline ppt & 46.4 & 10 & & 21 & 1 & 15 & 5 & 16 & 32 & 67 \\
\hline \multicolumn{11}{|c|}{$1 \mathrm{M} \mathrm{KOH}-1$} \\
\hline sn & 11.8 & 2 & 3 & 19 & 17 & 4 & 25 & 21 & 8 & 265 \\
\hline ppt & 5.0 & 10 & & 21 & 3 & 10 & 9 & 21 & 26 & 86 \\
\hline \multicolumn{11}{|c|}{$1 \mathrm{~m} \mathrm{KOH}-2$} \\
\hline sn & 36.6 & 2 & 3 & 9 & 25 & 1 & 20 & 37 & 3 & 947 \\
\hline ppt & 0.9 & 6 & & 24 & 7 & 10 & 12 & 29 & 12 & 78 \\
\hline \multicolumn{11}{|l|}{$4 \mathrm{M} \mathrm{KOH}$} \\
\hline sn & 100.4 & & 4 & 42 & 12 & & 16 & 18 & 8 & 941 \\
\hline ppt & 1.8 & 1 & 3 & 40 & 13 & & 13 & 20 & 18 & 593 \\
\hline \multicolumn{11}{|c|}{ Cellulosic residue-2 } \\
\hline sn-CR & 7.5 & 4 & 3 & 43 & & & 12 & 2 & 36 & 436 \\
\hline $\mathrm{CR}$ & 268.2 & 2 & 5 & & 4 & 2 & 1 & 81 & 5 & 298 \\
\hline
\end{tabular}

HexA, hexuronic acid; sn, supernatant on dialysis; ppt, precipitate on dialysis; blank spaces, not detected.

${ }^{a}$ Values are expressed as mg anhydrosugarg ${ }^{-1}$.

${ }^{b}$ Value is expressed as $\mathrm{g} \mathrm{kg}^{-1}$ raw material.

${ }^{c}$ Values are expressed as $\mathrm{g} \mathrm{kg}^{-1}$ AIR.

All extracts were analysed by FT-IR in the region $1200-850 \mathrm{~cm}^{-1}$ with application of PCA. ${ }^{23,24,42}$ The score scatter plot of the extracts (Fig 1(a)) showed a distribution along the PC1 axis according to the sugar content (see Table 1). The extracts poor in sugars were placed in PC1 positive, in opposition to the extracts with $100 \%$ sugars which were placed at the other extreme of the PC1 axis. PC2 of the score scatter plot distinguished the extracts according to the presence of pectic polysaccharides. The extracts rich in pectic polysaccharides were placed in PC2 negative. This was shown by the negative loadings of the wavenumbers characteristic of pectic polysaccharides (1020 and $\left.1100 \mathrm{~cm}^{-1}\right),{ }^{23}$ in the loading plot of Fig $1 \mathrm{~b}$. These results confirmed the sugar analysis of Table 1, showing that the majority of the water, chlorite and sn-CR extracts were mainly pectic polysaccharides.

\section{Analysis of graded ethanol-precipitated fractions}

In order to obtain a more precise characterisation of the major cell wall polysaccharides in the hazelnut seeds, the extracts 'chlorite sn', ' $1 \mathrm{~m} \mathrm{KOH-2} \mathrm{sn'} \mathrm{and}$ ' $4 \mathrm{M} \mathrm{KOH}$ sn', which contained the majority of the recovered carbohydrate material, were submitted to graded precipitation with ethanol (Table 2).

The chlorite extract, almost totally soluble in $80 \%$ ethanol solution, has a sugar composition characteristic of pectic polysaccharides. Graded ethanol precipitation gave, in both $\mathrm{KOH}$ extracts, a xyloglucan (4Glc:3.5Xyl:1Gal:0.5Fuc) which precipitates in $50-60 \%$ ethanol. It accounts for $30 \%$ of the material in the extract. Most of the polysaccharides in these two extracts $(50 \%)$ were recovered in the supernatant of the ethanol solutions (EtSN). Both fractions were rich in Ara, Gal and HexA, possibly of pectic origin.

The score scatter plot and loading plot of the FT-IR spectra in the region $1200-850 \mathrm{~cm}^{-1}$ of all ethanol fractions are shown in Fig 2. According to the loading profile, which was similar to PC1 of Fig 1, PC1 positive shows samples with a very low content of sugars (see Table 2). Considering the samples rich in sugars (placed in PC1 negative), three groups were formed according to PC2. PC2 positive contained the three samples with the highest amount of Glc and Xyl (Table 2). The second group contained the three samples with a relatively lower amount of these sugars, and the sample in PC2 negative was shown to contain only traces of these two sugar residues. According to the ${ }^{1} \mathrm{H}$ and ${ }^{13} \mathrm{C}$ NMR spectra of the major fraction, recovered from the supernatant of $4 \mathrm{M} \mathrm{KOH}$ and precipitated in a solution of $50 \%$ ethanol (Fig 3), the samples in PC2 positive showed resonance signals for 
(a)

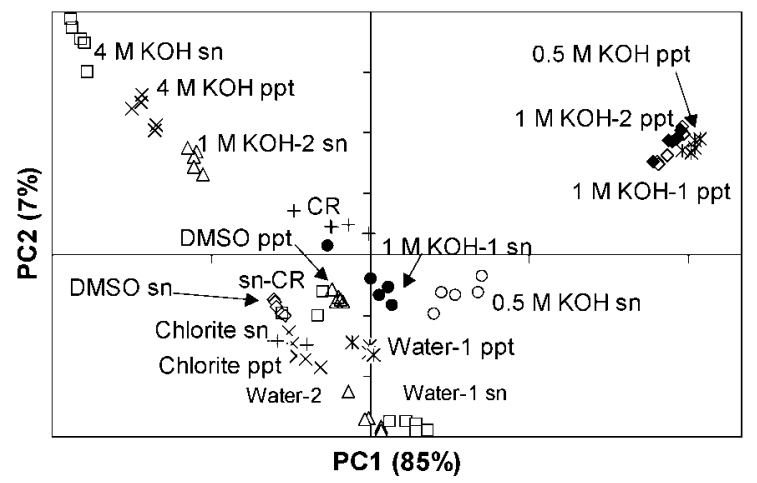

(b)

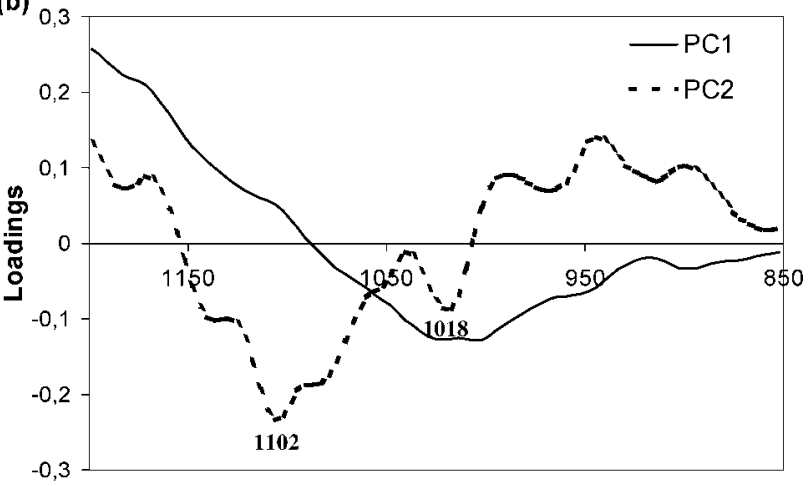

Wavenumbers $\left(\mathrm{cm}^{-1}\right)$

Figure 1. (a) Score scatter plot and (b) corresponding loading plot of FT-IR spectra in $1200-850 \mathrm{~cm}^{-1}$ region of AIR extracts.

C-1, C- 4 and C- 5 of $(1 \rightarrow 4,6)-\beta$-D-Glc $p(105.2,82.0$ and $77.6 \mathrm{ppm}$ respectively), for $\mathrm{C}-1$ and $\mathrm{C}-5$ of $(1 \rightarrow 2)$ $\alpha$-D-Xylp (102.2 and 63.8 ppm) and terminal- $\alpha-\mathrm{D}-\mathrm{Xyl} p$ $(101.7$ and $64.4 \mathrm{ppm})$, for $\mathrm{C}-1$ of $(1 \rightarrow 2)-\beta$-D-Galp $(106.0 \mathrm{ppm})$ and terminal- $\beta-\mathrm{D}-\mathrm{Gal} p(107.2 \mathrm{ppm})$ and for C- 6 of terminal- $\alpha$-L-Fuc $p$ (18.7 ppm). The anomeric protons of $(1 \rightarrow 2)-\alpha-\mathrm{D}-\mathrm{Xyl} p(5.15 \mathrm{ppm})$, terminal $-\alpha-$ $\mathrm{D}-\mathrm{Xyl} p(4.95 \mathrm{ppm})$ and terminal- $\alpha-\mathrm{L}-\mathrm{Fuc} p(5.28 \mathrm{ppm})$, (a)
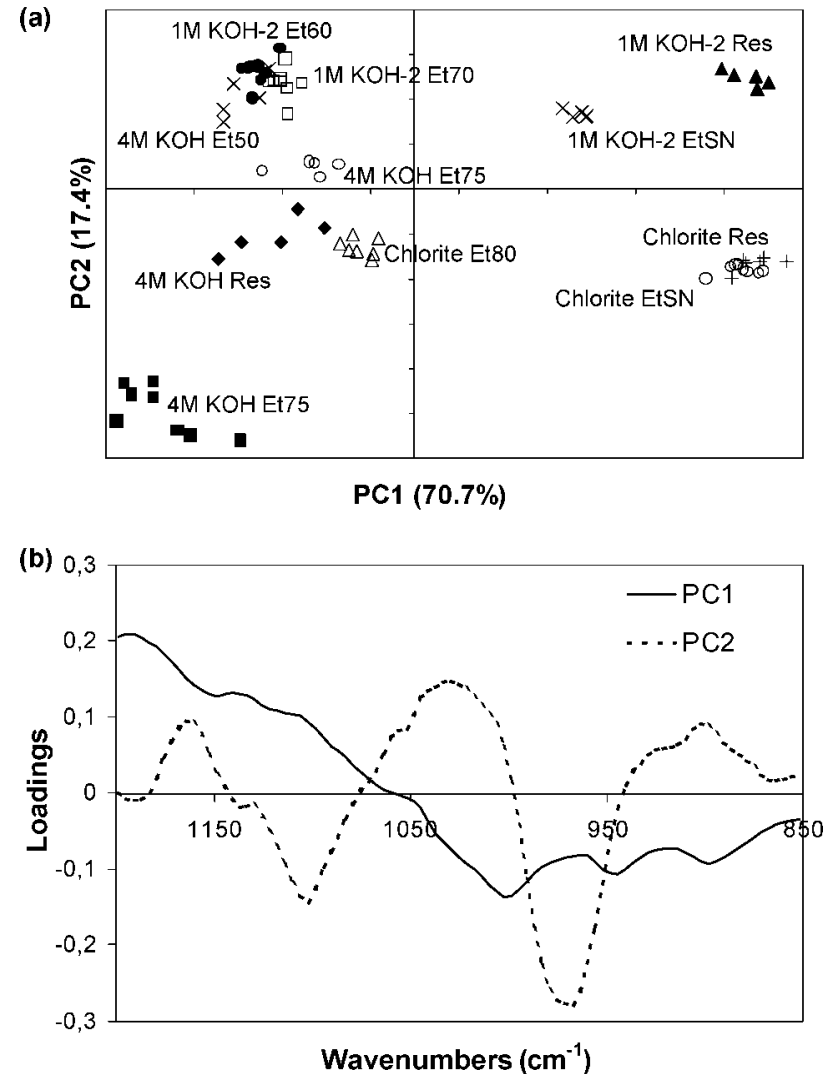

Figure 2. (a) Score scatter plot and (b) corresponding loading plot of FT-IR spectra in $1200-850 \mathrm{~cm}^{-1}$ region of ethanol fractions.

$\mathrm{H}-2$ of $(1 \rightarrow 4,6)-\beta$-D-Glc $p(3.41 \mathrm{ppm})$ and $\mathrm{H}-6$ of terminal- $\alpha-\mathrm{L}-\mathrm{Fuc} p(1.27 \mathrm{ppm})$ were also identified. These spectra are characteristic of xyloglucans. ${ }^{43-45}$

Based on the recovery yield and sugar composition of each cell wall extract, and their characterisation by FT-IR and ethanol precipitation, the relative percentages of pectic polysaccharides, xyloglucans and cellulose in cell walls were recalculated from the data

Table 2. Sugar composition of graded ethanol-fractionated cell wall fractions from Gevuina avellana seeds

\begin{tabular}{|c|c|c|c|c|c|c|c|c|c|c|}
\hline \multirow[b]{2}{*}{ Fraction } & \multirow{2}{*}{$\begin{array}{c}\text { Recovery } \\
\left(g k g^{-1}\right)\end{array}$} & \multicolumn{8}{|c|}{ Cell wall sugars (mol\%) } & \multirow{2}{*}{$\begin{array}{c}\text { Total sugars } \\
\quad\left(m g g^{-1}\right)\end{array}$} \\
\hline & & Rha & FuC & Ara & $x y l$ & Man & Gal & G/c & HexA & \\
\hline \multicolumn{11}{|l|}{ Chlorite sn } \\
\hline Residue & $98.0^{\mathrm{b}}$ & & 26 & 24 & $\operatorname{tr}$ & & 14 & 36 & & 23 \\
\hline Et80 & 429.1 & $\operatorname{tr}$ & 1 & 20 & 7 & 1 & 23 & 11 & 37 & 628 \\
\hline EtSN & 362.4 & $\operatorname{tr}$ & 15 & 70 & $\operatorname{tr}$ & & 10 & 5 & & 122 \\
\hline \multicolumn{11}{|c|}{$1 \mathrm{~m} \mathrm{KOH}-2 \mathrm{sn}$} \\
\hline Residue & 25.2 & & 2 & 2 & 29 & 1 & 19 & 39 & 8 & 179 \\
\hline Et60 & 279.8 & $\operatorname{tr}$ & 5 & $\operatorname{tr}$ & 38 & & 11 & 44 & 2 & 984 \\
\hline Et70 & 72.7 & $\operatorname{tr}$ & 5 & 2 & 35 & & 16 & 39 & 3 & 930 \\
\hline EtSN & 516.8 & 1 & $\operatorname{tr}$ & 29 & 9 & 1 & 38 & 11 & 11 & 277 \\
\hline \multicolumn{11}{|l|}{$4 \mathrm{~m} \mathrm{KOH} \mathrm{sn}$} \\
\hline Residue & 26.3 & 1 & 2 & 35 & 14 & & 12 & 19 & 17 & 989 \\
\hline Et50 & 329.7 & & 5 & $\operatorname{tr}$ & 38 & & 11 & 44 & 2 & 995 \\
\hline Et75 & 80.9 & 1 & 3 & 24 & 9 & & 25 & 12 & 26 & 960 \\
\hline EtSN & 505.2 & 1 & $\operatorname{tr}$ & 69 & tr & & 10 & 1 & 19 & 1060 \\
\hline
\end{tabular}

tr, trace; HexA, hexuronic acid; blank spaces, not detected.

${ }^{\text {a }}$ Values are expressed as $\mathrm{mg}$ anhydrosugar $\mathrm{g}^{-1}$.

b Values are expressed as $\mathrm{g} \mathrm{kg}^{-1}$ of initial ethanol-precipitated material. 

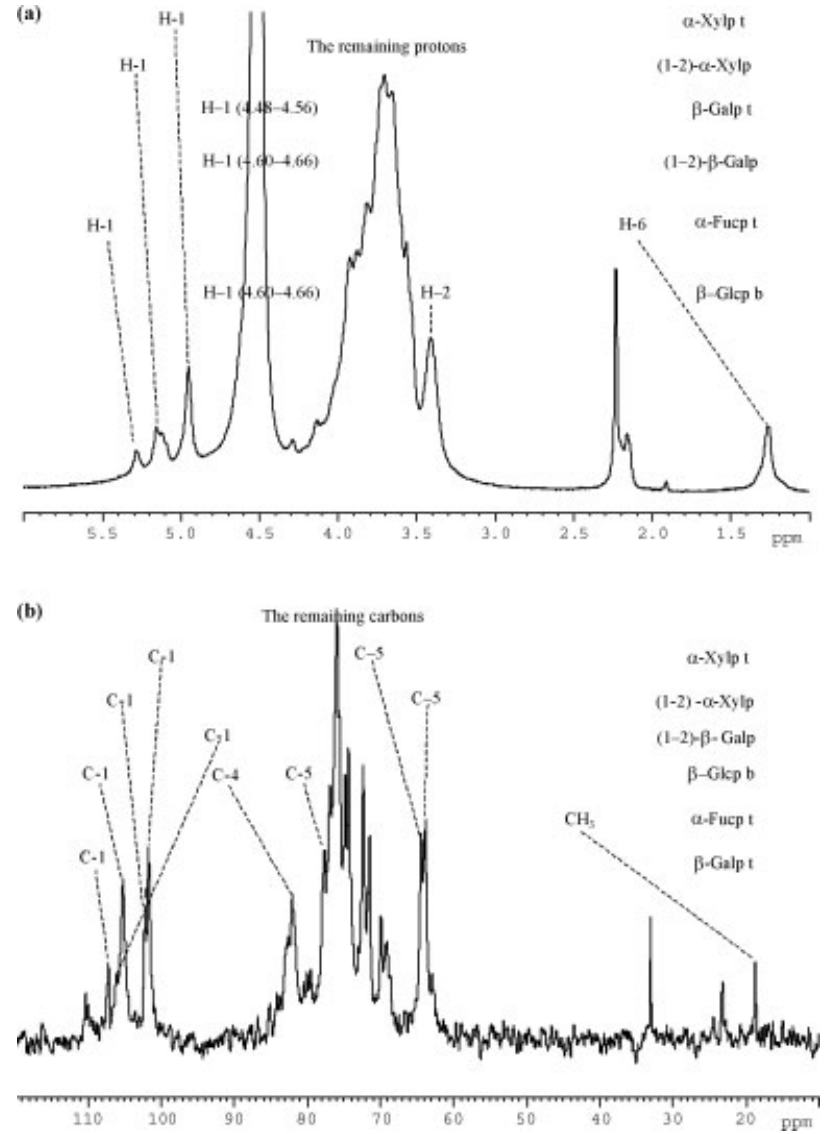

Figure 3. (a) ${ }^{1} \mathrm{H}$ and (b) ${ }^{13} \mathrm{C}$ NMR spectra of xyloglucan recovered in $4 \mathrm{M}$ $\mathrm{KOH}$ sn ET50 fraction, in $\mathrm{D}_{2} \mathrm{O}(\mathrm{b}$, branched; t, terminal).

presented in Table $1^{38,46}$ and it was shown that they occur in equal amounts.

\section{CONCLUSIONS}

The $G$ avellana seed structure is very simple. The mature embryo has two voluminous cotyledons, suggesting that this seed is an exalbuminous one. The internal organisation of the cotyledon cells is quite homogeneous. These cells have a high number of protein bodies.

The Chilean hazelnut cell wall polysaccharides are composed of equal amounts of pectic polysaccharides, xyloglucans and cellulose. The xyloglucan is highly branched with Xyl residues and contains Fuc, with a glycosidic composition of 4Glc:3.5Xyl:1Gal:0.5Fuc.

The FT-IR spectra in the $1200-850 \mathrm{~cm}^{-1}$ region were shown to be useful in evaluating the polysaccharide content in the cell wall extracts and in distinguishing the hemicellulosic from the pectic polysaccharide extracts. In addition, they allowed the identification of the xyloglucan-rich extracts.

\section{ACKNOWLEDGEMENTS}

This work was funded by INCO-DC programme 962205 (OLNOCO). The authors acknowledge Professor Artur Silva (University of Aveiro) for the NMR analysis, and the financial support of Research Unit 62/94, QOPNA (Aveiro, Portugal). A Barros thanks FCT (Portugal) for post-doctoral grant PRAXIS XXI/ $\mathrm{BPD} / 18824 / 99$.

\section{REFERENCES}

1 Brett CT and Waldron KW, The molecular components of the wall, in Physiology and Biochemistry of Plant Cell Walls, 2nd edn, Chapman and Hall, London, pp 6-43 (1996).

2 Fry SC, The Growing Plant Cell Wall: Chemical and Metabolic Analysis. Longmans, Essex, UK, pp 102-187 (1988).

3 Imeson A, Thickening and Gelling Agents for Food, 3rd edn, Blackie Academic and Professional, London (1996).

4 Sanderson GR, Polysaccharides in foods. Food Technol 35:50-57, 86 (1981).

5 Ring SG and Selvendran RR, Isolation and analysis of cell wall material from beeswing wheat bran (Triticum aestivum). Phytochemistry 19:1723-1730 (1980).

6 Englyst $\mathrm{HN}$ and Cummings $\mathrm{JH}$, Simplified method for the measurement of total non-starch polysaccharides by gas-liquid chromatography of constituent sugars as alditol acetates. Analyst 109:937-942 (1984).

7 Bonvehí JS and Coll FV, Study of the carbohydrate fraction of the principal varieties of Tarragona hazelnuts (Corylus avellana L). Food Chem 46:285-288 (1993).

8 Slominski BA and Campbell LD, Non-starch polysaccharides of canola meal: quantification, digestibility in poultry and potential benefit of dietary enzyme supplementation. $\mathcal{F} \mathrm{Sci}$ Food Agric 53:175-184 (1990).

9 Jung HJ, Valdez FR, Hatfield RD and Blanchette RA, Cell wall composition and degradability of forage stems following chemical and biological delignification. I Sci Food Agric 58:347-355 (1992).

10 Balasubramainam K, Polysaccharides of the kernel of maturing and matured coconuts. F Food Sci 41:1370-1373 (1976).

11 Ben-Shalom N, Hindrance of hemicellulose and cellulose hydrolysis by pectic substances. F Food Sci 51:720-721, 730 (1986).

12 Düsterhoft E-M and Voragen AGJ, Non-starch polysaccharides from sunflower (Helianthus annuus) meal and palm kernel (Elaeis guineenis) meal-preparation of cell wall material and extraction of polysaccharide fraction. I Sci Food Agric 55:411422 (1991).

13 Düsterhoft E-M, Posthumus MA and Voragen AGJ, Non-starch polysaccharides from sunflower (Helianthus annuus) meal and palm kernel (Elaeis guineenis) meal-investigation of the structure of major polysaccharides. F Sci Food Agric 59:151160 (1992).

14 Henriksson K, Teleman A, Suortti T, Reinikainen T, Jaskari J, Teleman $\mathrm{O}$ and Poutanen $\mathrm{K}$, Hydrolysis of barley $(1 \rightarrow 3)$, $(1 \rightarrow 4)$ - $\beta$-D-glucan by a cellobiohydrolase II preparation from Trichoderma reesei. Carbohydr Polym 26:109-119 (1995).

15 Ollé D, Baron A, Lozano YF and Brillouet J-M, Enzymatic degradation of cell wall polysaccharides from mango (Manifera indica L) puree. F Agric Food Chem 48:2713-2716 (2000).

16 Brandt LM, Jeltema MA, Zabik ME and Jeltema BD, Effects of cooking in solutions of varying $\mathrm{pH}$ on the dietary fiber components of vegetables. F Food Sci 49:900-904, 909 (1984).

17 Jiménez A, Guillén R, Fernández-Bolaños J and Heredia A, Cell wall composition of olives. F Food Sci 59:1192-1995, 1201 (1994).

18 Edwards M, Vegetables and fruit, in Food Texture, Ed by Rosenthal AJ, Aspen Publishers, Gaithersburg, MD, pp 259278 (1999).

19 Qi B, Moore KG and Orchard J, Effect of cooking on banana and plantain texture. F Agric Food Chem 48:4221-4226 (2000).

20 Yamada H, Pectic polysaccharides from Chinese herbs: structure and biological activity. Carbohydr Polym 25:269-276 (1994). 
21 Srivastava R and Kulshreshtha DK, Bioactive polysaccharides from plants. Phytochemistry 28:2833-2877 (1989).

22 Cheung PCK and Leë MY, Fractionation and characterization of mushroom dietary fiber (nonstarch polysaccharides) as a potential nutraceutical from sclerotia of Pleurotus tuber-regium (Fries) Singer. F Agric Food Chem 48:3148-3151 (2000).

23 Coimbra MA, Barros A, Barros M, Rutledge DN and Delgadillo I, Multivariate analysis of uronic acid and neutral sugars in whole pectic samples by FT-IR spectroscopy. Carbohydr Polym 37:241-248 (1998).

24 Coimbra MA, Barros A, Rutledge DN and Delgadillo I, FT-IR spectroscopy as a tool for the analysis of olive pulp cell wall polysaccharide extracts. Carbohydr Res 317:145-154 (1999).

25 Ferreira D, Barros A, Coimbra MA and Delgadillo I, Use of FTIR spectroscopy to follow the effect of processing in cell wall polysaccharide extracts of a sun-dried pear. Carbohydr Polym 45:175-182 (2001).

26 Villarroel MT, Biolley EH, Schneeberger RK, Ballester DC and Santibáñez SR, Composicion química y calidad biologica de harina desgrasada de Avellana. Arch Latinoam Nutr 31:200211 (1989).

27 Christensen FM, Extraction by aqueous enzymatic processes. INFORM 2:984-987 (1991).

28 Clark G, Staining Procedures, 4th edn, Williams and Wilkins, Baltimore, MD, pp 317, 323, 325-327 (1981).

29 Gahan PB, Plant Histochemistry and Cytochemistry. An Introduction, Academic Press, London, pp 190, 204 (1984).

30 Bancroft JD and Stevens A, Theory and Practice of Histological Techniques. Churchill Livingstone, New York, p 220 (1996).

31 Coimbra MA, Delgadillo I, Waldron KW and Selvendran RR, Isolation and analysis of cell wall polymers from olive pulp, in Modern Methods of Plant Analysis, Vol 17, Ed by Linskens HF and Jackson JF, Springer, Berlin, pp 19-44 (1996).

32 Blumenkrantz $\mathrm{N}$ and Asboe-Hansen G, New method for quantitative determination of uronic acids. Anal Biochem 54:484-489 (1973).

33 Rutledge DN and McIntyre P, A proposed European implementation of JCAMP. DX format. Chemometrics Intell Lab Syst 16:95-101 (1992).

34 Barros AS, Contribution à la sélection et la comparaison de variables caractéristiques. PhD Thesis, Institut National Agronomique Paris-Grignon (1999).
35 Foster AS and Gifford Jr EM, Comparative Morphology of Vascular Plants, 2nd edn, WH Freeman, San Francisco, CA, p 722 (1974).

36 Bewley D and Black M, Seeds: Physiology of Development and Germination, 2nd edn, Plenum, New York, pp 21-25 (1986).

37 Garcia-Mas J, Messeguer R, Arús P and Piugdomènech P, Molecular characterization of cDNAs corresponding to genes expressed during almond (Prunus amygdalus Batsch) seed development. Plant Mol Biol 27:205-210 (1995).

38 Dourado F, Vasco P, Gama FM, Coimbra MA and Mota M, Characterisation of Rosa mosqueta seeds: cell wall polysaccharides composition and light microscopy observations. F Sci Food Agric 80:1859-1865 (2000).

39 Selvendran RR and O'Neill MA, Isolation and analysis of cell walls from plant material, in Methods of Biochemical Analysis, Vol 32, Ed by Glick D, Wiley, New York, pp 25-153 (1987).

40 Holland B, Unwin DI and Buss HD, Fruits and Nuts-the First Supplement to Macance and Widdowson's The Composition of Foods, 5th edn, Royal Society of Chemistry/Ministry of Agriculture Fisheries and Food (1992).

41 Jermyn MA and Isherwood FA, Changes in the cell wall of the pear during ripening. Biochem f 64:123-132 (1956).

42 Jolliffe IT, Principal Component Analysis. Springer, New York (1986).

43 Hisamatsu M, York WS, Darvill AG and Albersheim P, Characterization of seven xyloglucan oligosaccharides containing from seventeen to twenty glycosyl residues. Carbohydr Res 227:45-71 (1992).

44 Braccini I, Hervé du Penhoat C, Michon V, Goldberg R, Clochard M, Jarvis MC, Huang Z-H and Gage DA, Structural analysis of cyclamen seed xyloglucan oligosaccharides using cellulase digestion and spectroscopic methods. Carbohydr Res 276:167-181 (1995).

45 Watt DK, Brasch DJ, Larsen DS and Melton LD, Isolation, characterisation, and NMR study of xyloglucan from enzymatically depectinised and non-depectinised apple pomace. Carbohydr Polym 39:165-180 (1999).

46 Mafra I, Lanza B, Reis A, Marsilio V, Campestre C, De Angelis $M$ and Coimbra MA, Effect of ripening on texture, microstructure and cell wall polysaccharide composition of olive fruit (Olea europaea). Physiol Plant 111:439-447 (2001). 